\title{
Surgical removal of entrapped guidewire fragment following direct circumflex artery angioplasty and stenting
}

\author{
Wojciech Domaradzki ${ }^{1}$, Krzysztof Sanetra ${ }^{1}$, Bartosz Skwarna², Marek Król², Małgorzata Kuczera ${ }^{3}$, \\ Marek Cisowski ${ }^{1}$ \\ ${ }^{1} 1^{\text {st }}$ Department of Cardiac Surgery, American Heart of Poland, Bielsko-Biała, Poland \\ ${ }^{2} 1^{\text {st }}$ Department of Cardiology and Angiology, American Heart of Poland, Ustroń, Poland \\ ${ }^{3}$ Department of Anaesthesiology and Intensive Care, American Heart of Poland, Bielsko-Biała, Poland
}

Kardiochirurgia i Torakochirurgia Polska 2015; 12 (3): 242-245

\begin{abstract}
We present a case of a 64-year-old man with coronary artery disease, who underwent a percutaneous coronary intervention of the circumflex artery. As the guidewire was being withdrawn from the target vessel, it became entrapped by the structure of the previously implanted stent. Attempts to retrieve the foreign body were unsuccessful. Changes in electrocardiogram were observed during the procedure, and the level of cardiac biomarkers increased within the next 24-hours. The patient was admitted to the Cardiac Surgery Department. Remnants of the foreign body were removed under visual control using extracorporeal circulation, and coronary artery bypass grafting was performed. Treatment options and outcomes are discussed.

Key words: $C A B G, P C l$, guidewire.
\end{abstract}

\section{Introduction}

Constant progress and the dynamic introduction of new technological solutions have enabled the application of transcutaneous interventions in increasingly complex coronary lesions while reducing the number of possible adverse events. Notwithstanding, even during simple procedures of invasive cardiology, the risk of complications such as the inability to withdraw the guidewire or other elements of the stent kit from the artery should be taken into account. The frequency of such events is estimated at $0.1-0.2 \%$ of all coronary angioplasty attempts [1, 2]. The foreign body can typically be removed from the vessel using a simple technique during the same procedure in a haemodynamic room [3]. Surgical intervention appears to be indicated in cases in which the foreign object cannot be removed endovascularly, especially if the removal is necessitated by the patient's condition.

\section{Streszczenie}

W pracy przedstawiono przypadek 64-letniego mężczyzny z chorobą niedokrwienną serca poddanego procedurze przezskórnej interwencji wewnątrznaczyniowej w zakresie tętnicy okalającej. W trakcie wycofywania prowadnicy doszło do jej zaklinowania o strukturę implantowanego wcześniej stentu. Pomimo licznych prób nie udało się wycofać ciała obcego z naczynia. Podczas zabiegu obserwowano zmiany w elektrokardiogramie, w kolejnej dobie wzrost markerów uszkodzenia mięśnia sercowego. Pacjenta przekazano na Oddział Kardiochirurgii i przy użyciu krążenia pozaustrojowego usunięto pod kontrolą wzroku prowadnicę oraz wykonano zabieg pomostowania aortalno-wieńcowego. Opcje terapeutyczne i rokowania nadal stanowią przedmiot dyskusji.

Stowa kluczowe: $\mathrm{CABG}, \mathrm{PCl}$, prowadnica.

\section{Case study}

The following report presents the case of a 64-year-old patient; before admission, he had been diagnosed with ischaemic heart disease, first-degree atrioventricular block, arterial hypertension, lipid metabolism disorders, and paroxysmal atrial fibrillation. His medical history included angioplasty of the anterior interventricular branch of the left coronary artery (left anterior descending - LAD) with bare-metal stent (BMS) implantation in 2005, a repeat LAD angioplasty with drug-eluting stent (DES) implantation due to restenosis (December 12, 2012), and angioplasty of the right coronary artery (RCA) with DES implantation (January 10,2013$)$. The patient was admitted to the $1^{\text {st }}$ Department of Cardiology and Angiology of the American Heart of Poland Clinic in Ustron in order to undergo another stage of endovascular treatment. The procedure was performed using femoral artery access, with the use of a guiding

Address for correspondence: Krzysztof Sanetra, $1^{\text {st }}$ Department of Cardiac Surgery, American Heart of Poland, 101 Armii Krajowej St., 43-316 Bielsko-Biała, Poland, phone: +48 692030003, e-mail: krzyssan@poczta.onet.pl 
catheter (EBU 3.5, 6F). After the guidewire was introduced into the circumflex branch of the left coronary artery $(C x)$, a drug-eluting stent was implanted directly in the medial segment of $C x$ at a pressure of 16 atm, covering the outlet of the second obtuse marginal artery (OM2). The procedure was performed without any difficulty; full dilatation of the stented vessel was achieved, and no significant stenosis was present in the outlet of OM2 (Fig. 1 and 2). The time between femoral artery puncture and stent implantation amounted to approx. 12 minutes, the duration of fluoroscopy was 3 minutes, and the dose of radiation was 548 mGy. A decision was made to withdraw the coronary

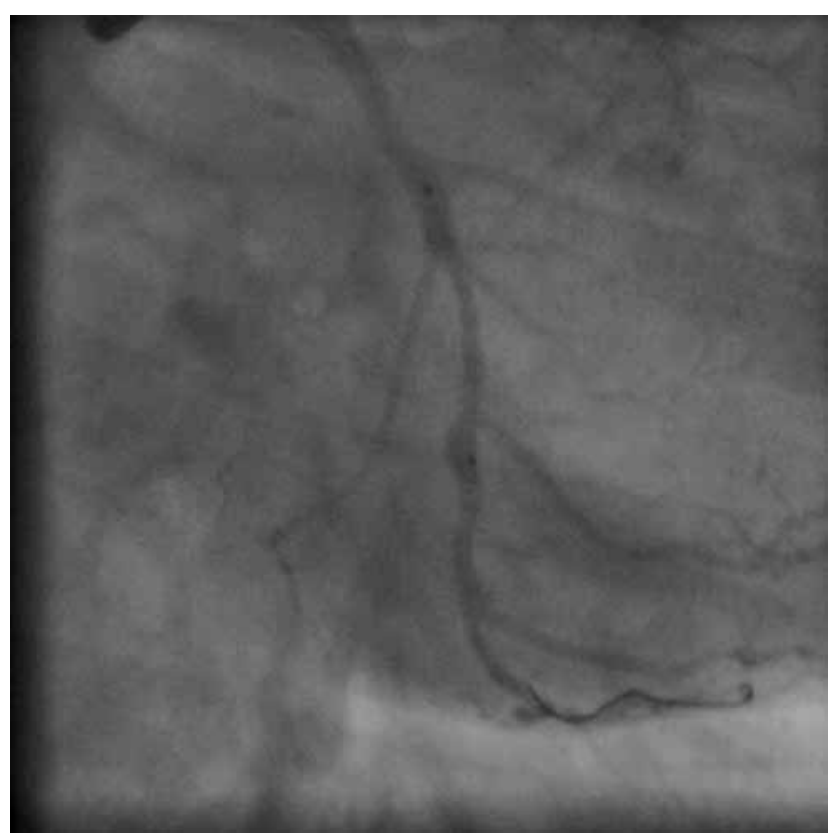

Fig. 1. Stent positioning

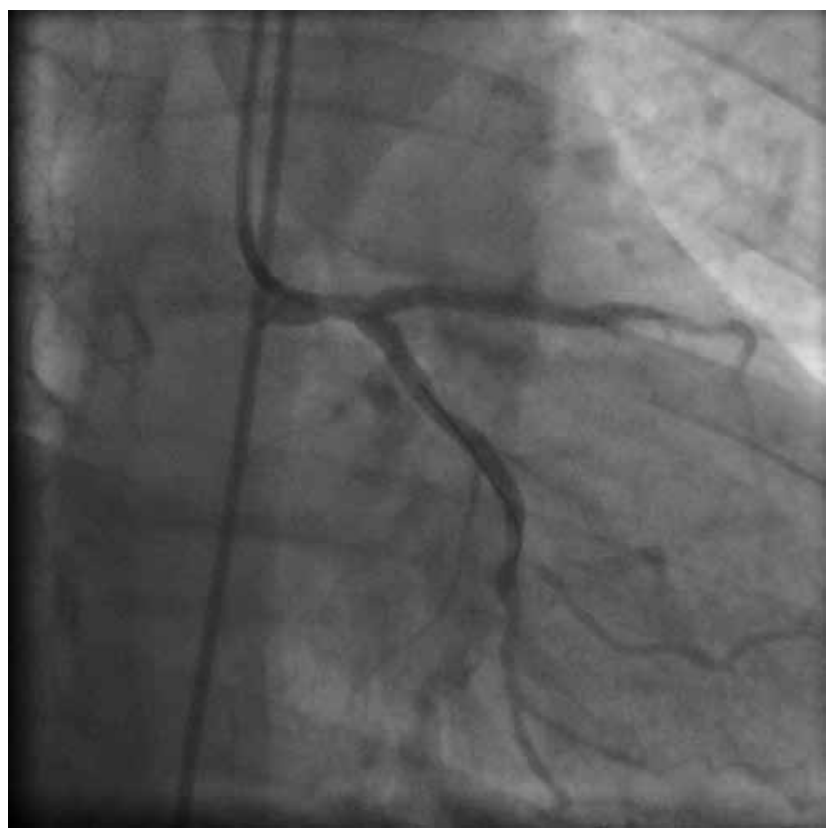

Fig. 3. The entrapped guidewire guidewire in order to perform a final angiographic examination. As the guidewire was being withdrawn from the vessel, its distal end became caught on the stent structure (Fig. 3). Many attempts were made to free the guidewire; an angioplastic balloon was placed over it, and a series of manipulations was performed. Due to a strong pull, the structure of the stent became deformed, and the distal segment of the guidewire was severed (Fig. 4 and 5). Vascular stenosis recurred in the location where the stent was implanted, and a significant deceleration of flow was observed (Fig. 6); the obtained electrocardiogram demonstrated ST-segment elevation in the leads above the inferolateral wall. Another

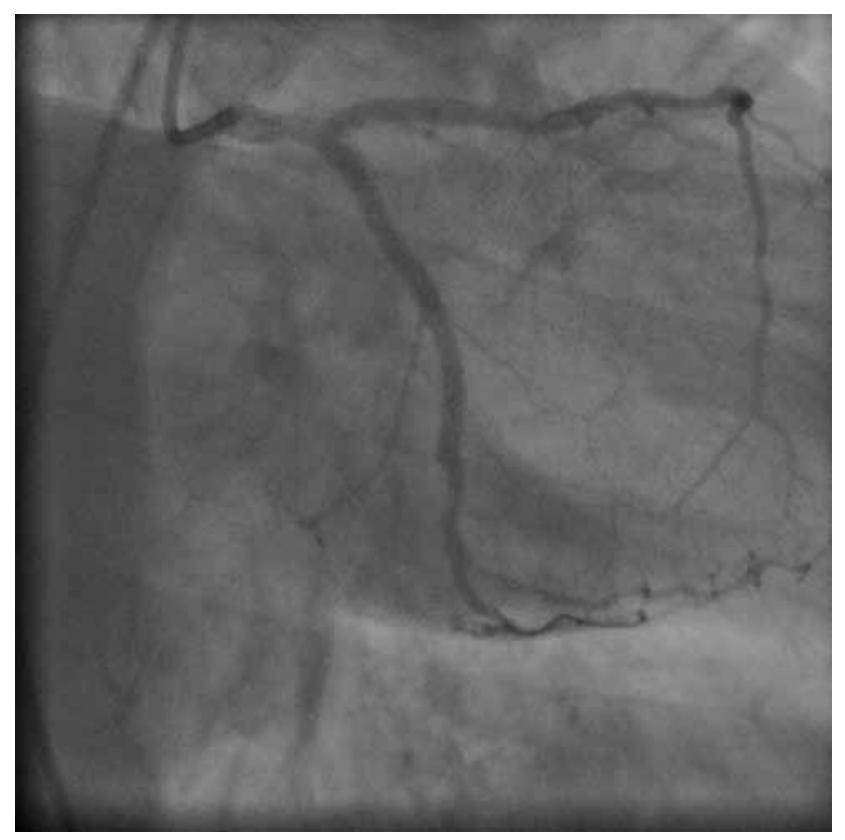

Fig. 2. The immediate effect after stent implantation

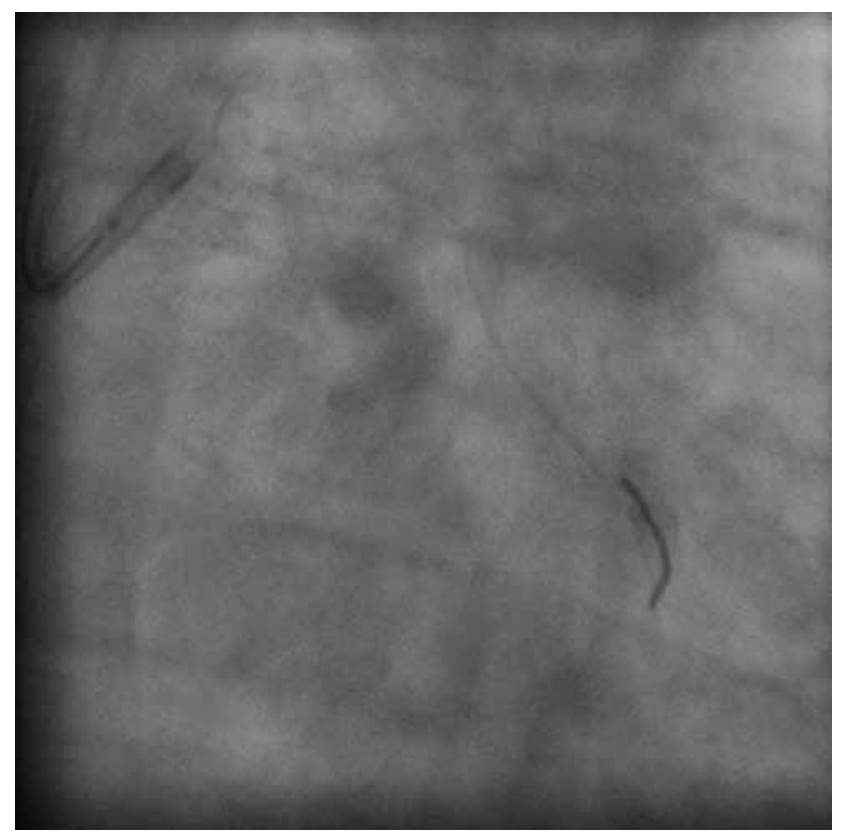

Fig. 4. The separated distal fragment of the guidewire, the deformed stent, and a short fragment of the guidewire core reinforcement 


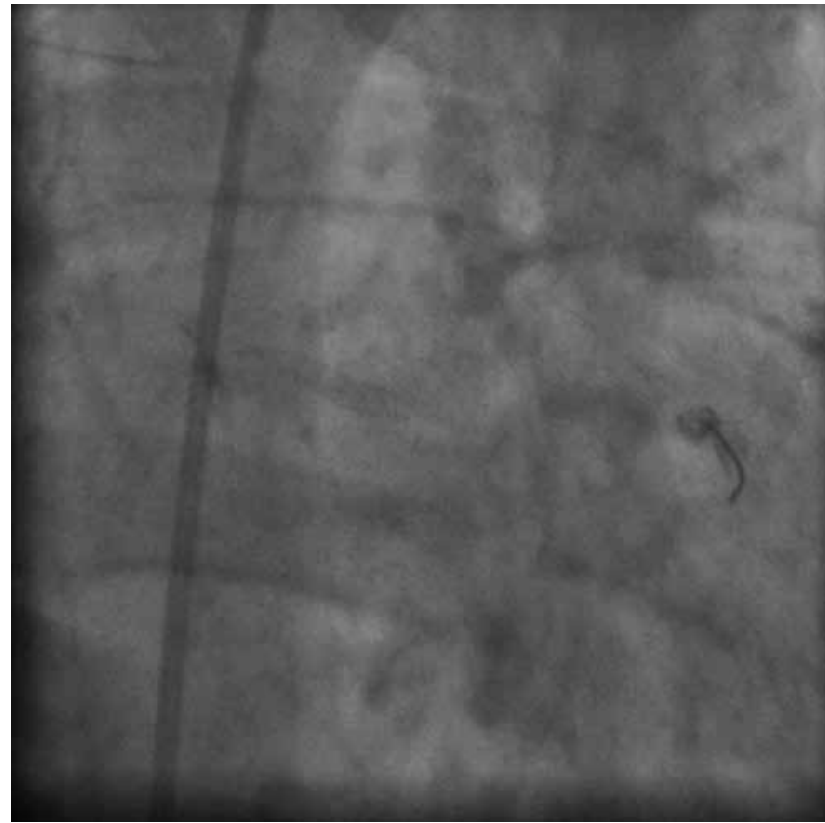

Fig. 5. The separated fragment of the guidewire, the deformed stent, and a partially coiled fragment of the guidewire reinforcement structure

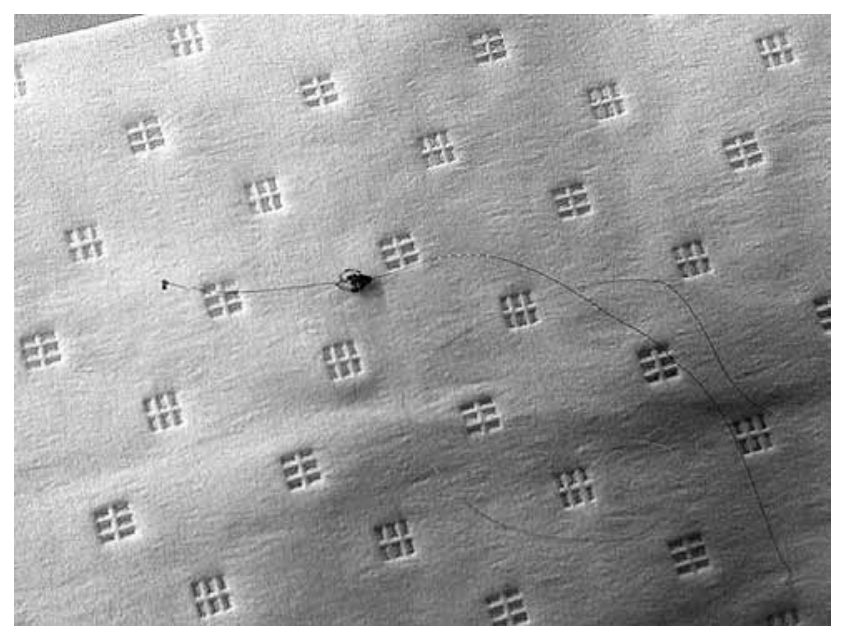

Fig. 7. The removed guidewire and deformed stent

guidewire was introduced into the $\mathrm{Cx}$, but the attempt to deploy another balloon through the deformed stent structure was unsuccessful (Fig. 6). The time of the procedure reached 120 minutes, the duration of fluoroscopy amounted to 41 minutes, and the patient received a radiation dose of 6695 mGy. Unfractionated heparin was introduced, and ACT was monitored. On the next day, a significant elevation of markers of myocardial necrosis was observed, meeting the criteria for the diagnosis of type $4 a$ myocardial infarction. Control echocardiography demonstrated no new disturbances of segmental contractility and showed that global left ventricular systolic function (LVEF) had not deteriorated. The patient's condition was stable. After a consultation, the patient was qualified for surgical treatment.

On admission to the Department of Cardiac Surgery, the patient presented with chest pain (CCS class III) and

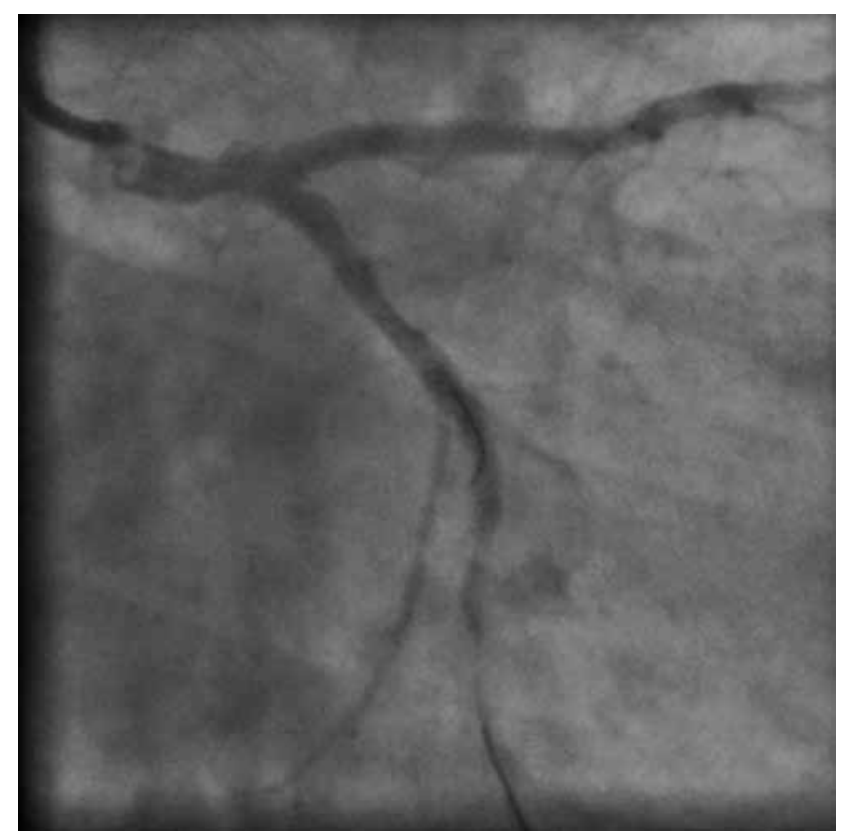

Fig. 6 . The second coronary guidewire introduced into the lumen of circumflex artery (CX); stenosis recurrence visible in the location where the stent was implanted

dyspnoea (NYHA class II). The heart was beating in a regular, sinus rhythm (73 bpm); arterial pressure amounted to $130 / 80 \mathrm{mmHg}$. Left ventricular ejection fraction was evaluated at 55\% using echocardiography. Doppler ultrasonography of the carotid arteries showed numerous atherosclerotic changes, but the flow spectrum was normal.

On February 7, 2013, a procedure was conducted under extracorporeal circulation: the ascending aorta was opened, and the guidewire was removed from the aorta under visual control. Subsequently, using the same approach, the distal part of the guidewire and the deformed stent were removed from the circumflex artery by being pulled into the aortic lumen (Fig. 7). As the patency of the coronary vessel could not have been reliably evaluated, an AoCx bypass was created using the patient's saphenous vein. The time of extracorporeal circulation was 35 minutes, and aortic clamp time amounted to 24 minutes. Postoperative mechanical ventilation was maintained for 10 hours. Total drainage amounted to $295 \mathrm{ml}$. The peri- and postoperative periods were uneventful. On the sixth postoperative day the patient was transferred to the Cardiac Rehabilitation Centre; he was no longer experiencing pain, his breathing and circulation were stable, and his wounds were healing by first intention.

\section{Discussion}

Foreign bodies left behind in coronary vessels after transcutaneous endovascular interventions constitute a significant issue, primarily due to the lack of clear guidelines concerning their surgical management. Taking under consideration the typically complex clinical background appears to be of particular importance. The problem may pertain to any artery, and the management method is indi- 
vidualised based on the perioperative course and the risk of potential complications [4-6]. In most cases in which part of the guidewire becomes separated, the separation occurs before the implantation of the stent; however, there are reports describing instances in which the guidewire became wedged in the vessel after the intervention [7]. Typically, the latter situation is associated with a greater risk if a decision to remove the guidewire is made.

The necessity to remove the fragments left behind in the vessel usually stems from the patient's condition, as well as the high risk of infection, perforation, arrhythmia, and progressive thrombosis. Leaving behind fragments of small foreign bodies, usually contained within a completely and chronically occluded artery or its distal part, is not associated with any clinical implications $[2,8]$. The risk of arterial injury associated with attempts to forcibly remove the remnants from the vessel should therefore be considered with particular care. In such cases, isolated bypass grafting appears to be the optimal treatment, especially in view of existing studies reporting favourable prognosis [8, 9]. The fragments of a foreign body must be removed if they are located within the ascending aorta due to the high risk of cerebral vascular embolisation [8].

Due to the high number of endovascular interventions, a significant rise in the number of patients with similar clinical profiles should be expected. The presented case illustrates how a simple direct stenting procedure may become complicated. Of note is the significant extension of the duration of the procedure, the time of fluoroscopy, and the dose of radiation. This points to the need for careful consideration when selecting patients for revascularisation procedures, and strict cooperation between departments of interventional cardiology and cardiac surgery, and heart team consultations.

\section{Disclosure}

Authors report no conflict of interest.

\section{References}

1. van den Brand M, de Feyter P, Serruys P, Zijlstra F, Bos E. Fracture of a balloon on a wire device during coronary angioplasty. Cathet Cardiovasc Diagn 1989; 16: 253-257.

2. Hartzler GO, Rutherford BD, McConahay DR. Retained percutaneous transluminal coronary angioplasty equipment components and their management. Am J Cardiol 1987; 60: 1260-1264.

3. Bloomfield DA. The nonsurgical retrieval of intracardiac foreign bodies - an international survey. Cathet Cardiovasc Diagn 1978; 4: 1-14.

4. Rosario PG, Donahoo JS. Coronary artery endarterectomy for retrieval of entrapped percutaneous angioplasty catheter. Ann Thorac Surg 1996; 61: 218-219.

5. Sethi GK, Ferguson TB, Miller G, Scott SM. Entrapment of broken guidewire in the left main coronary artery during percutaneous transluminal coronary angioplasty. Ann Thorac Surg 1989; 47: 455-457.

6. Proctor MS, Koch LV. Surgical removal of guidewire fragment following transluminal coronary angioplasty. Ann Thorac Surg 1988; 45: 678-679.

7. Karthik S, Silverton P, Blaxill JA, O'Regan DJ. Successful outcome of emergency coronary artery bypass grafting and retrieval of entrapped stent, angioplasty balloon, and guidewire. Ann Thorac Surg 2005; 79: 1032-1034.

8. Alexiou K, Kappert U, Knaut M, Matschke K, Tugtekin SM. Entrapped coronary catheter remnants and stents: must they be surgically removed? Tex Heart Inst J 2006; 33: 139-142.

9. Yajima T, Sakakibara T, Ida T, Tsunemoto H, Ootaki E, Suzuki S. Entrapment of broken guidewire in the right coronary artery during percutaneous transluminal coronary angioplasty. Nihon Kyobu Geka Gakkai Zasshi 1991; 39: 1813-1815. 